ORIGINAL RESEARCH PAPER

\title{
THE INFLUENCE OF INCUBATION TEMPERATURE AND STARTER CULTURE TYPE ON PHYSICAL PROPERTIES OF AYRAN
}

\author{
FIRUZE ERGIN* \\ Akdeniz University, Department of Food Engineering, Faculty of Engineering, Turkey \\ Corresponding author: fergin@akdeniz.edu.tr \\ Received on 28 December 2020 \\ Revised on 26 April 2021
}

\begin{abstract}
In this study, the effects of the incubation temperature and type of starter culture on the physical properties, including graininess and visual roughness, of ayran were determined. Ayran samples were produced from milk inoculated with two different starter cultures (Yo-Mix 410, Yo-Mix 883) and incubated at temperatures of 37 or $45^{\circ} \mathrm{C}$, and then stored at $4^{\circ} \mathrm{C}$ for 15 days. As incubation temperature decreased the number and perimeter of grains and syneresis decreased and the amount of exopolysaccharide (EPS) increased in ayran samples. The high amount of EPS resulted in low syneresis value, the number and perimeter of grains and visual roughness in ayran samples. The apparent viscosity and consistency coefficient values of ayran samples produced from milk incubated at $37^{\circ} \mathrm{C}$ were higher than those from milk incubated at $45^{\circ} \mathrm{C}$. The Power law model was found more satisfactory to describe flow behaviour of all ayran samples. The rheological properties of ayran samples changed with measurement temperature. As the measurement temperature increased from $5^{\circ} \mathrm{C}$ to $15^{\circ} \mathrm{C}$, the apparent viscosity and consistency coefficient values of ayran samples were significantly decreased. The activation energy values for apparent viscosity of ayran samples varied depending on the incubation temperature, type of starter culture and storage period.
\end{abstract}

Keywords: ayran, graininess, incubation temperature, rheology, starter culture, visual roughness

\section{Introduction}

In recent years, the consumption of fermented dairy products has increased due to their potential health and nutritional benefits. Ayran, one of the traditional fermented dairy products in Turkey, is produced by two different methods as traditional and industrial methods. In the traditional method, ayran is prepared by adding water and salt to yoghurt under continuous stirring for 1-2 min at room temperature (Erkaya et

https://doi.org/10.35219/foodtechnology.2021.1.07 
al., 2015; Tamer et al., 2019). In the industrial method, total solids content of milk is standardized to about $8 \%$ by adding water. The total solids-standardized milk is fermented with yoghurt bacteria (Streptococcus thermophilus and Lactobacillus delbrueckii subsp. bulgaricus) at $42^{\circ} \mathrm{C}$ until its $\mathrm{pH}$ value reaches between 4.2-4.6, then the salt is added and stirred to produce ayran. Besides, ayran should have a minimum titratable acidity of $0.5 \%$, a minimum milk protein content of $2.0 \%$, and a maximum salt content of $1.0 \%$ (Atalay, 2017). The health-promoting properties of fermented dairy products and as well as their physical properties such as serum separation, texture, and rheology play an important role in the quality and consumer acceptance (Nguyen et al., 2018).

Graininess (non-dispersible particles) and roughness (irregularities in protein gel) are undesirable texture defects in ayran, which restrict production of smooth, uniform and fine-bodied products preferred by consumers (Küçükçetin, 2012). The presence of graininess and roughness in dairy products depends on whey protein and fat contents of milk, the addition of polysaccharides, type of starter culture, smoothing and stirring of product after fermentation, etc. (Rasmussen et al., 2007). However, there is only one study in the literature, performed by Küçükçetin (2012), investigating on graininess and roughness of ayran, which was produced from skimmed milk with different casein to whey ratios.

The preferred consumption temperature of ayran, which is cold-stored fermented dairy beverage, is below room temperature (Atalay, 2017). Moreover, the rheological properties of fermented dairy products, which influence the overall properties of the final products, can change with temperature (Penna et al., 2001; Ramaswamy and Basak, 1991). For manufacturers, knowing the effect of product temperature on the properties of product is important to optimize processing conditions and produce it with high quality (Álvarez et al., 2006).

In previous studies, the effects of casein to whey protein ratio of milk, water and salt contents of ayran, starter culture type (non-EPS and EPS producing), application of ultrasound energy, using transglutaminase and hydrocolloids on the physicochemical and rheological properties of ayran were investigated (Erkaya et al., 2015; Koksoy and Kilic, 2004; Köksoy and Kiliç, 2003; Küçükçetin, 2012; Yilmaz et al., 2015). The objective of this research was to study the combined effect of the different starter cultures and incubation temperatures on physical properties, including the graininess and roughness, of the ayran. Furthermore, the flow behaviour of ayran samples were investigated at measurement temperatures of 5,10 and $15^{\circ} \mathrm{C}$ and the activation energy values were determined.

\section{Materials and methods}

\section{Ayran Production}

Raw cow's milk (11.62\% total solids, $3.18 \%$ fat, $3.21 \%$ protein, $6.7 \mathrm{pH}$ ) provided by the Dairy Processing Unit of the Faculty of Agriculture at Akdeniz University (Antalya, Turkey) was skimmed to about $0.1 \%$ fat using a cream separator (G140 model, SMS Ltd. Co., Kayseri, Turkey) at $55^{\circ} \mathrm{C}$. For the ayran production, deionized 
water was added to the skimmed milk to give the final total solids content of about $8 \%$. Skimmed milk-water mixture, called ayran milk, was heated at $90^{\circ} \mathrm{C}$ for $5 \mathrm{~min}$, then it was divided into two parts: one part was cooled to $37^{\circ} \mathrm{C}$ and the other to $45^{\circ} \mathrm{C}$. The cooled ayran milks were inoculated with $0.2 \mathrm{~g} \mathrm{~L}^{-1}$ of starter culture Yo-Mix 410 or Yo-Mix 883 supplied by Danisco (Türker Industry Technic Machine Inc., Istanbul, Turkey). Yo-Mix 410 is a starter culture recommended for high-viscosity dairy products. However, Yo-Mix 883 contains a strain of Streptococcus thermophilus CNCM I-2980 which is modified for production of EPS that provides very high viscosity and low graininess in yoghurt and ayran (Patent number US7582743B2 issued on August 19, 2013). The inoculated ayran milks were incubated at $37^{\circ} \mathrm{C}$ or $45^{\circ} \mathrm{C}$ until the pH reached to about 4.6 and then cooled to $20^{\circ} \mathrm{C}$, after cooling, salt $(0.5 \%$, w/v, Billur Tuz Co. Ltd., İzmir, Turkey) was added and stirred using a mechanical mixer (Bosch, Mixxo Quattro MSM 7700, Jesenice, Slovenia) for $2 \mathrm{~min}$. The ayran samples were packaged in $200-\mathrm{mL}$ polystyrene cups with lids and stored at $4^{\circ} \mathrm{C}$ for 15 days. Some physical properties of the ayran samples were determined on days 1 and 15 of storage.

\section{Analyses for milk and ayran samples}

\section{Proximate analysis}

The total solids, fat and protein contents of the milk and ayran samples were analysed by the gravimetric method, the Gerber method and the Kjeldahl method, respectively (Erkaya et al., 2015). The percentage of titratable acidity values for the ayran samples were performed using the methods of Erkaya et al. (2015). The $\mathrm{pH}$ values of the milk and the ayran samples were measured using a $\mathrm{pH}$-meter (Thermo Scientific Orion 2-Star, Bremen, Germany).

Syneresis value

For the determination of the syneresis values of the ayran samples, the samples were placed in volumetric cylinders and stored at $4{ }^{\circ} \mathrm{C}$ for 15 days. The volume of separated serum at the top was read after storage 1 and 15 days (Koksoy and Kilic 2004).

\section{EPS content}

The EPS contents of the ayran samples were determined following the method of Purwandari et al. (2007). The ayran samples were treated with ethanol followed by trichloroacetic acid (TCA) to precipitate the proteins. The EPS-containing precipitate was dissolved with $10 \mathrm{~mL}$ of distilled water. This procedure for EPS purification using ethanol, TCA and distilled water was repeated twice more. Then, the EPS was vacuum dried at $55^{\circ} \mathrm{C}$ and weighed. The results were expressed as the amount of crude EPS per kilogram of ayran.

\section{Microbiological properties}

The counts of S. thermophilus in the ayran samples were enumerated using M17 agar (Merck KGaA, Darmstadt, Germany). The plates were incubated in anaerobic conditions at $37^{\circ} \mathrm{C}$ for $48 \mathrm{~h}$. For the enumeration of L. delbrueckii subsp. bulgaricus, MRS agar (Merck KGaA, Darmstadt, Germany) was used and the plates were incubated at $37^{\circ} \mathrm{C}$ for $72 \mathrm{~h}$ (Yilmaz et al., 2015). 


\section{Graininess and visual roughness}

The number and the perimeter of grains -called graininess, were determined by image analysis according to the method described by Küçükçetin et al. (2012). Realscale images of the ayran samples were obtained with a digital camera (EOS 450D, Canon Inc., Tokyo, Japan) (Figure 3 a-d). The perimeters of grains greater than 1.0 $\mathrm{mm}$ were calculated using an image processing software (Bs200, BAB Image Analysing Systems Inc., Ankara, Turkey). The software was set for the evaluation of $3 \mathrm{~mL}$ ayran samples. The visual roughness (Rvis) was taken as an additional descriptive parameter for the graininess of the ayran samples. The Rvis was calculated using a protocol described by Küçükçetin et al. (2012). The microscopic image of the ayran samples was taken at 10x magnifications by a fluorescent microscope (MCX300, MICROS Produktions und Handels GmbH, Veit/Glan, Austria) (Figure 2 a-h) (Gilbert et al., 2020).

\section{Rheological properties}

Rheological properties of the ayran samples were performed using a Brookfield R/S plus rheometer (Brookfield, Middleboro, MA, USA) equipped with a concentric cylinder double gap (DG3) geometry assembly following the method described by Köksoy and Kiliç (2003). After gentle mixing by ten up and down movements of a spoon in the ayran cup, about $20 \mathrm{~mL}$ of ayran samples were deposited in the geometry assembly of the rheometer. The ayran samples were started to be analysed after waiting for approximately $2 \mathrm{~min}$ in the measuring gap to achieve thermal equilibrium. The samples were sheared by linearly increasing shear rate from 0.1 to $300 \mathrm{~s}^{-1}$ for $5 \mathrm{~min}$ and reducing back to $0.1 \mathrm{~s}^{-1}$ in the next $5 \mathrm{~min}$. Viscosity values in the up-ward viscosity to shear rate curves at a shear rate of $50 \mathrm{~s}^{-1}$ were taken as the apparent viscosity of the ayran samples (Koksoy and Kilic 2004). Rheological measurements of the ayran samples were carried out at three different measurement temperatures of 5,10 and $15^{\circ} \mathrm{C}$ using a water bath (Brookfield TC-502). The Newtonian flow, Power-law, Bingham and Herschel-Bulkey models were compared using Rheo3000 software (RheotecMesstechnik GmbH, Berlin, Germany) to find suitable rheological model fitting the experimental shear stress-shear rate.

The effect of the measurement temperatures on apparent viscosity values of the ayran samples was described by the Arrhenius models (Equation 1);

$$
\eta=A \exp \left(\frac{E a}{R T}\right)
$$

where $A$ (Pa.s) is the constant, $E a$ is the activation energy terms $\left(\mathrm{kJ} \mathrm{mol}^{-1}\right), \mathrm{R}$ is the gas constant $\left(\mathrm{kJ}(\mathrm{molK})^{-1}\right)$ and $\mathrm{T}$ is the absolute temperature $(\mathrm{K})$. The activation energy was determined from the slope of In $\eta$ vs. $\mathrm{T}^{-1}$ plot (Karazhiyan et al., 2009; Sabanc1 et al., 2016).

\section{Sensory properties}

The sensory properties of the ayran samples on the $1^{\text {st }}$ and $15^{\text {th }}$ days of storage were conducted according to the modified method of Bodyfelt (1988) by a panel of 11 
participants ( 5 females and 6 males from Department of Food Engineering of the Akdeniz University) who were trained on the sensory testing procedure. The participants had no reported medical complications that might influence the taste and aroma perception conditions. The ayran samples were kept in a water bath to achieve target tasting temperatures of 5,10 and $15^{\circ} \mathrm{C}$, before the sensory analysis. All the samples were presented with three-digit codes and were evaluated for texture, taste, aroma and total acceptability in a scale from 1 to 5 describing low to high acceptability, respectively.

\section{Statical analysis}

All statistical calculations were performed using SAS Statistical Software (release for Windows, SAS Institute Inc., Cary, NC, USA). Duncan's multiple range test was used to detect differences between the treatment means. In this study, each variation of production and storage for ayran was performed in triplicate.

\section{Results and discussion}

\section{Proximate analysis results}

The mean total solids, fat, protein and ash contents of the ayran samples ranged from 7.95 to $8.08 \%$, from 0.12 to $0.14 \%$, from 2.99 to $3.07 \%$, and from 0.79 to $0.82 \%$, respectively. In Figures $1 \mathrm{a}-\mathrm{f}$, the changes in the $\mathrm{pH}$, titratable acidity and syneresis values, the EPS content, and the counts of S. thermophilus and L. delbrueckii subsp. bulgaricus of the ayran samples are illustrated. The $\mathrm{pH}$ values of the samples varied from 4.61 to 4.64 and from 4.46 to 4.56 between the first day and $15^{\text {th }}$ days of storage. The titratable acidity values ranged between $0.62 \%$ and $0.64 \%$ for one-day stored samples and between $0.64 \%$ and $0.71 \%$ for 15 -day stored samples.

\section{The EPS content}

The ayran samples produced from milk inoculated with Yo-Mix 883 had higher EPS contents compared to the ayran samples produced from milk inoculated with YoMix 410 on the first day of storage. The studies showed that the EPS content depends on strain characteristic of $S$. thermophilus and L. delbrueckii subs. bulgaricus in the ayran and yoghurt samples (Marshall and Rawson, 1999; Yilmaz et al., 2015). The EPS content in the ayran samples produced from milk incubated at $37^{\circ} \mathrm{C}$ significantly was higher than those from milk incubated at $45^{\circ} \mathrm{C}$ during the storage period. Purwandari et al. (2007), in a study on investigation of the effect of the use of different strains of EPS-producing Streptococcus thermophilus as S. thermophilus ST 1275 and S. thermophilus ST 285 and different incubation temperatures (30, 37 and $42^{\circ} \mathrm{C}$ ) on the physicochemical properties of set-type yoghurt, presented that the highest content of EPS was determined in the yoghurt samples manufactured from milk inoculated with $S$. thermophilus ST 285 and incubated at $37^{\circ} \mathrm{C}$. Furthermore, Mende et al. (2016) reported that the yield of EPS by thermophilic lactic acid bacteria increased at their optimum growth temperatures. 

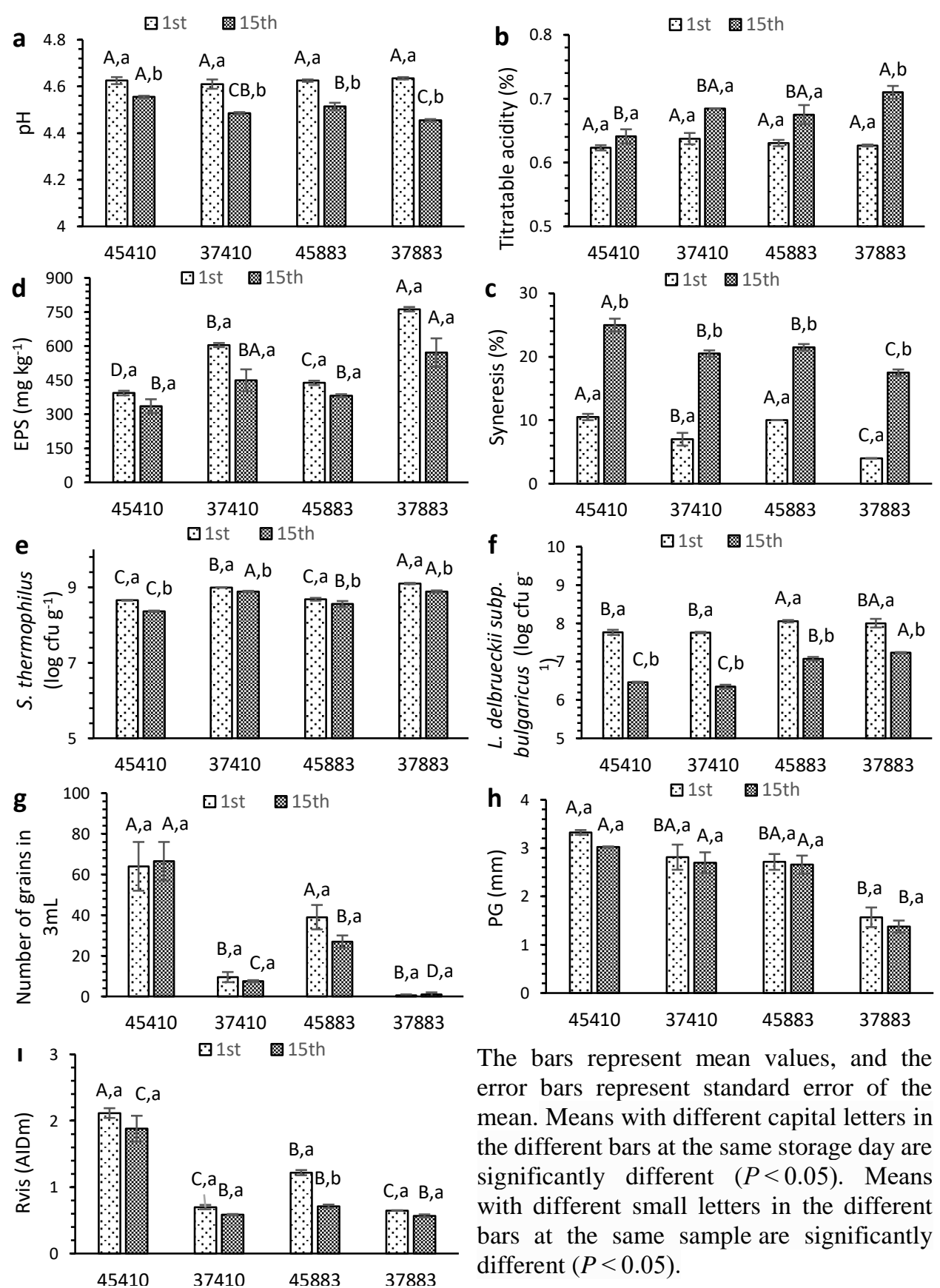

The bars represent mean values, and the error bars represent standard error of the mean. Means with different capital letters in the different bars at the same storage day are significantly different $(P<0.05)$. Means with different small letters in the different bars at the same sample are significantly different $(P<0.05)$.

Figure 1. (a) $\mathrm{pH}$ value, (b) titratable acidity value (\%), (c) EPS content $\left(\mathrm{mg} \mathrm{kg}^{-1}\right)$, (d) syneresis value (\%), (e) Streptococcus thermophilus count (log cfu g $\left.{ }^{-1}\right)$, (f) L. delbrueckii subp. bulgaricus count $\left(\log \mathrm{cfu}^{-1}\right),(\mathrm{g})$ the number of grains, (h) mean perimeter of grains (PG, $\mathrm{mm}$ ) and (1) visual roughness value (AIDm, mean absolute intensity deviation) of the ayran samples produced from milk incubated with Yo-Mix 410 at $45^{\circ} \mathrm{C}(45410)$ and $37^{\circ} \mathrm{C}$ (37410) and with Yo-Mix 883 at $45^{\circ} \mathrm{C}(45883)$ and $37^{\circ} \mathrm{C}(37883)$. 


\section{The syneresis value}

The syneresis value of the ayran samples produced from milk incubated at $45^{\circ} \mathrm{C}$ was significantly higher than that produced from milk incubated at $37^{\circ} \mathrm{C}$ on the first day of the storage. The result of the present study was in agreement with previous studies reported by Lee and Lucey (2004) and Purwandari et al. (2007), in which the syneresis of yoghurt samples decreased significantly as incubation temperature decreased due to formation of weak gel and large pores in yoghurt gel. Regardless of the incubation temperature, higher syneresis values were observed in the ayran samples produced from milk inoculated with Yo-Mix 410 in comparison to those from milk inoculated with Yo-Mix 883 at the end of the storage. This may be related to the differences in EPS producing abilities of yoghurt bacteria in the starter cultures. The EPS has a water-binding ability and may attach to protein surface and form interactions between different protein particles or other milk constituents (Yang et al., 2014).

\section{Microbiological properties}

In the present study, the counts of $S$. thermophilus in the ayran samples produced from milk incubated at $37^{\circ} \mathrm{C}$ were higher than those from milk incubated at $45^{\circ} \mathrm{C}$, while the counts of $L$. delbrueckii subs. bulgaricus were not significantly affected by the incubation temperature. Erkaya et al. (2015) studied the effect of thermosonication on some properties of ayran and determined that the counts of $S$. thermophilus and L. delbrueckii subs. bulgaricus of ayran samples were between $<1$ $8.82 \log \mathrm{cfu} \mathrm{mL} \mathrm{mL}^{-1}$ and $<1-6.80 \log \mathrm{cfu} \mathrm{mL}^{-1}$, respectively, at the end of the 30-day storage. Yilmaz et al. (2015) found that the counts of the S. thermophilus and $L$. delbrueckii subs. bulgaricus of ayran samples ranged between $8.28-7.38 \mathrm{log}$ cfu $\mathrm{mL}^{-1}$ and $6.59-4.09 \log \mathrm{cfu} \mathrm{mL} \mathrm{m}^{-1}$, respectively, after 1 day of storage. The authors reported that the counts of both bacteria in the ayran samples can vary according to their strain types. The differences in counts of S. thermophilus and L. delbrueckii subs. bulgaricus between the present study and previous studies may be associated with differences in strains of yoghurt bacteria in starter culture and as well as ayran processing methods.

\section{Graininess and visual roughness}

The number of grains in the ayran samples produced from milk incubated at $45^{\circ} \mathrm{C}$ was higher than those from milk incubated at $37^{\circ} \mathrm{C}$. The number of grains in the ayran samples produced from milk inoculated with Yo-Mix 410 was higher than those from milk inoculated with Yo-Mix 883, regardless of the incubation temperature (Figure 1).

The graininess and roughness of yoghurt and ayran can be affected by incubation temperature and time, type of starter culture, addition of polysaccharides in yoghurt milk and difference in milk composition used in the ayran production (Küçükçetin et al., 2012; Rasmussen et al., 2007). Guirguis et al. (1987) reported that the effects of starter culture type on the graininess of yoghurts may be related to acidification rate of starter bacteria. In another study, Williams et al. (2003) also determined that the number and mean perimeter of grains in yoghurt samples obtained using a high- 
level EPS producing starter culture were lower than those made using a medium or low-level EPS producing starter cultures. As reported by Rasmussen et al. (2007), graininess was found to be less pronounced in yoghurt when EPS-producing yoghurt starter bacteria was used. Duboc and Mollet (2001) also pointed out that the texture of stirred yoghurt from milk inoculated with non-EPS producing yoghurt starter bacteria tended to be granular. The real-scale and microscopic-scale images of the ayran samples were presented in Figure 2. In Figure 2, darkness zones show aggregated protein particles, while the light pores are considered as serum phase. The ayran samples produced from milk inoculated with Yo-Mix 883 and incubated at $37^{\circ} \mathrm{C}$ had smaller pores and homogeneous protein network compared to those from milk inoculated with Yo-Mix 410 and incubated at $45^{\circ} \mathrm{C}$, respectively. At higher incubation temperature, hydrophobic interactions in the protein gel increases, which result in rearrangements of gel network, and pore size increases (Lee and Lucey, 2004). Moreover, the authors reported that the EPS might compensate for the rearrangements of casein particle in the yoghurt gel network and reduce syneresis (Abbasi et al., 2009; Cartesev and Rudic, 2017).

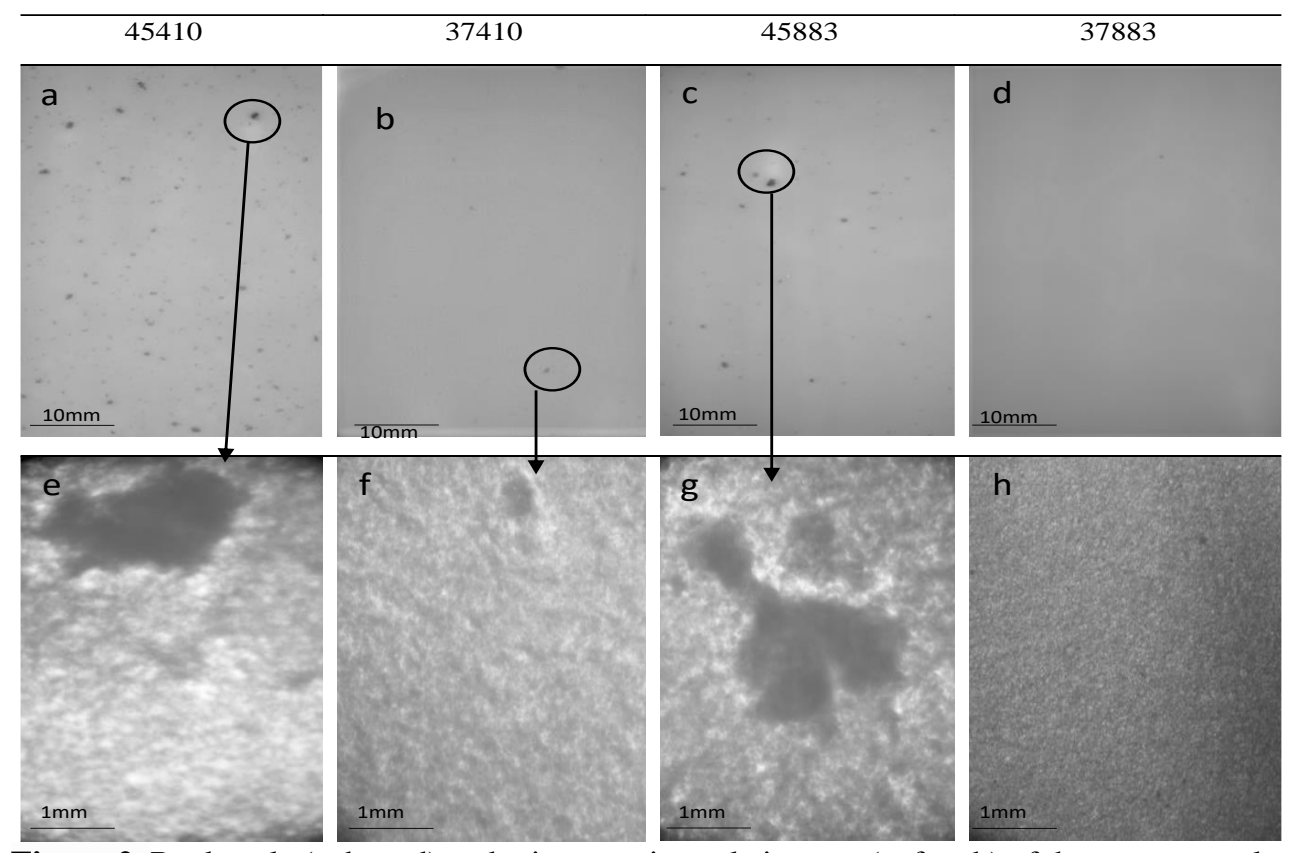

Figure 2. Real-scale (a, b, c, d) and microscopic-scale images (e, f, g, h) of the ayran samples after a day of storage. The ayran samples produced from milk incubated with Yo-Mix 410 at $45^{\circ} \mathrm{C}$ (45410- a and e), with Yo-Mix 410 at $37^{\circ} \mathrm{C}$ (37410- $b$ and f), with Yo-Mix 883 at $45^{\circ} \mathrm{C}$ (45883, c and g) and with Yo-Mix 883 at $37^{\circ} \mathrm{C}(37883, \mathrm{~d}$ and h).

\section{Rheological properties}

As expected, the apparent viscosity values of the ayran samples produced from milk incubated at $37^{\circ} \mathrm{C}$ were higher in comparison to those from milk inoculated at $45^{\circ} \mathrm{C}$ 
(Table 1). It could be attributed to the aggregation of casein that occurs more slowly at low incubation temperatures resulting in more interactions in protein particles and less rearrangements of the particles during gel formation compared to high incubation temperatures (Sodini et al., 2004). Nevertheless, this study results differ to the findings of some previous studies which reported that the apparent viscosity values of the ayran samples increased with the incubation temperature (Ozdemir and Kilic, 2004; Yilmaz et al., 2015).

Table 1. The effects of incubation temperature, types of starter culture, storage time and measurement temperature on the values of apparent viscosity, consistency coefficient and flow behaviour index of the ayran samples.

\begin{tabular}{|c|c|c|c|}
\hline Samples & $\begin{array}{l}\text { Apparent } \\
\text { viscosity (Pa.s) }\end{array}$ & $\begin{array}{l}\text { Flow behaviour } \\
\text { index }(\eta)\end{array}$ & $\begin{array}{l}\text { Consistency } \\
\text { coefficient }\left(\text { Pa.s }^{\mathrm{n}}\right)\end{array}$ \\
\hline $\begin{array}{l}\text { Incubation temperature } \\
\left({ }^{\circ} \mathrm{C}\right)\end{array}$ & $* * *$ & ns & $*$ \\
\hline 37 & $0.16 \pm 0.03^{\mathrm{a}}$ & $0.46 \pm 0.03^{\mathrm{a}}$ & $1.03 \pm 0.08^{\mathrm{a}}$ \\
\hline 45 & $0.12 \pm 0.03^{\mathrm{b}}$ & $0.46 \pm 0.04^{\mathrm{a}}$ & $0.99 \pm 0.07^{\mathrm{b}}$ \\
\hline Types of starter culture & $* * *$ & $* * *$ & ns \\
\hline Yo-Mix 410 & $0.14 \pm 0.04^{\mathrm{b}}$ & $0.48 \pm 0.03^{\mathrm{a}}$ & $1.01 \pm 0.08^{\mathrm{a}}$ \\
\hline Yo-Mix 883 & $0.15 \pm 0.04^{\mathrm{a}}$ & $0.45 \pm 0.03^{\mathrm{b}}$ & $1.00 \pm 0.07^{\mathrm{a}}$ \\
\hline Storage (day) & $* * *$ & $* * *$ & $*$ \\
\hline 1 & $0.14 \pm 0.04^{b}$ & $0.47 \pm 0.04^{\mathrm{a}}$ & $0.99 \pm 0.04^{b}$ \\
\hline 15 & $0.15 \pm 0.04^{\mathrm{a}}$ & $0.45 \pm 0.03^{b}$ & $1.03 \pm 0.09^{\mathrm{a}}$ \\
\hline $\begin{array}{l}\text { Measurement temperature } \\
\left({ }^{\circ} \mathrm{C}\right)\end{array}$ & $* * *$ & $* * *$ & $*$ \\
\hline 5 & $0.19 \pm 0.03^{\mathrm{a}}$ & $0.44 \pm 0.02^{\mathrm{c}}$ & $1.02 \pm 0.08^{\mathrm{a}}$ \\
\hline 10 & $0.13 \pm 0.02^{b}$ & $0.46 \pm 0.02^{\mathrm{b}}$ & $1.01 \pm 0.05^{\mathrm{ab}}$ \\
\hline 15 & $0.11 \pm 0.02^{\mathrm{c}}$ & $0.49 \pm 0.04^{\mathrm{a}}$ & $0.98 \pm 9.04^{\mathrm{b}}$ \\
\hline
\end{tabular}

Values are the means \pm standard error $(n=3)$; different superscript letters for each parameter in a column show significant differences using Duncan's multiple range test $(\mathrm{P}<0.05)$. ns; non-significant, $* \mathrm{P}<0.05, * * \mathrm{P}<0.01, * * * \mathrm{P}<0.001$

In the present study, a positive relationship between the amount of EPS and the apparent viscosity values of the ayran samples was observed. The apparent viscosity values of the ayran samples might be affected by the amounts of produced organic acids and EPS which depend on strain of yoghurt bacteria used in the production of ayran. There are two different views on the effects of the EPS content on ayran viscosity. According to the first, EPS causes a weak protein network and lower apparent viscosity in the ayran because it prevents protein-protein interactions (Ozdemir and Kilic 2004). According to the other view, the EPS production increases the apparent viscosity of the ayran because EPS interacts with proteins and yoghurt bacteria (Yilmaz et al., 2015). The interaction between the EPS and proteins 
causes a dense network gel due to Van der Waals force and electrostatic interaction (Yang et al., 2014). The apparent viscosity values of the ayran samples decreased with increasing in measurement temperature (Table 1, Figure 3). As with the apparent viscosity values of the ayran samples, this result may be due to a decrease in the hydrodynamic forces in between particles and an increase in the mobility of the macromolecules in the aqueous food systems when the measurement temperature increased (Karazhiyan et al., 2009). Similar results were also reported for lactic beverages (Penna et al., 2001) and stirred yoghurt (Ramaswamy and Basak, 1991). This may be explained by the fact that viscosity of fluids depends on intermolecular forces and spaces. The spaces in fluids increase with increasing temperatures and thus, the viscosity of fluids decreases (Bakshi and Smith, 1984). The results of the present study are similar to findings of Yilmaz et al. (2015) that reported apparent viscosity values of ayran between 0.006 and $0.293 \mathrm{~Pa} \cdot \mathrm{s}$ at measurement temperature of $5^{\circ} \mathrm{C}$. Moreover, as the storage time prolonged, the apparent viscosity values of the ayran samples increased in the present study, which was in agreement with the study by Erkaya et al. (2015).

The Newtonian flow, Power law, Bingham and Herschel-Bulkey models were compared to analyse the flow behaviour of the ayran samples. Among these models, the Power law model had higher correlation coefficients $\left(\mathrm{R}^{2}\right)$ values (greater than 0.94) for all measurement temperatures, and hence this model was found more satisfactory to describe the flow behaviour of the ayran samples. Gursoy et al. (2016), Koksoy and Kilic (2003), Küçükçetin et al. (2012), Ozdemir and Kilic (2004) and Yilmaz et al. (2015) who determined the rheological properties of the ayran samples at temperature of $5^{\circ} \mathrm{C}$ or $10^{\circ} \mathrm{C}$, also used the Power law model. The flow behaviour index values of the ayran samples ranged from 0.41 to 0.54 and all ayran samples behaved as shear thinning fluid.

The flow behaviour index values of the ayran samples produced from milks inoculated with Yo-Mix 883 were found to be lower than those of the ayran samples produced from milks inoculated with Yo-Mix 410 (Table 1). It may certainly be attributed to $S$. thermophilus and L. delbrueckii subs. bulgaricus strains from the starter cultures, which produced EPS with different yields (Purwandari et al., 2007). Koksoy and Kilic (2004) also found that an increase in concentration of carbohydrate-based stabilizers used in ayran production caused a decrease in the flow behaviour index values of ayran samples. 

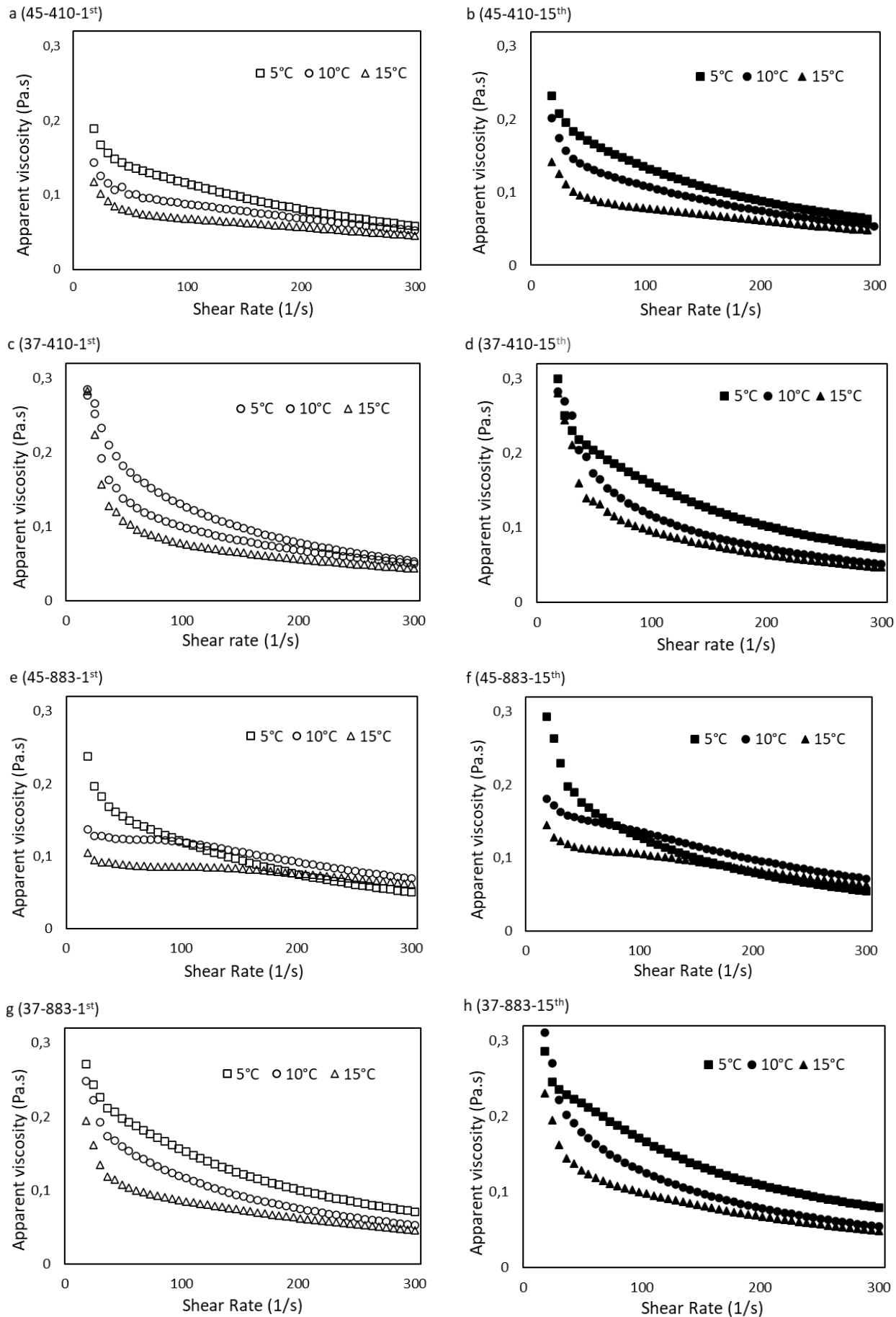

Figure 3. Changes in the apparent viscosity with shear rate in the ayran samples on the first $(\mathrm{a}, \mathrm{c}, \mathrm{e}, \mathrm{g})$ and $15^{\text {th }}(\mathrm{b}, \mathrm{d}, \mathrm{f}, \mathrm{h})$ days of storage at measurement temperatures of $5^{\circ} \mathrm{C}(\square, \boldsymbol{\square})$, $10^{\circ} \mathrm{C}(\circ, \bullet)$ and $15^{\circ} \mathrm{C}(\Delta, \boldsymbol{\Delta})$. 
The Arrhenius model was used to describe the effect of incubation temperature on the apparent viscosity values of the ayran samples (Table 2). The Ea values of the ayran samples produced from milks inoculated with Yo-Mix 410 and incubated at $45^{\circ} \mathrm{C}$ were higher than those from milks inoculated with Yo-Mix 883 and $37^{\circ} \mathrm{C}$, respectively. The high activation energy shows that apparent viscosity of the samples become more sensitive to changes in temperature (Sabanc1 et al., 2016). In a study performed by Gonçalves et al. (2017), the activation energy for apparent viscosity of yoghurt, fermented dairy beverage and fermented milk samples were determined as $15.26,21.00$ and $19.57 \mathrm{kj} \mathrm{mol}^{-1}$, respectively, at temperatures of between $5^{\circ} \mathrm{C}$ and $25^{\circ} \mathrm{C}$. They investigated that the yoghurt sample had lower activation energy than other counterparts because it had a lower moisture content. Moreover, Sun et al. (2014) reported that as the EPS content in aqueous solution increased, the activation energy for apparent viscosity decreased. In the present study, considering the results of the above-mentioned studies, the differences among the activation energy values of the samples might be related to formation of gel network which was affected by the incubation temperature and type of starter culture used in the ayran productions.

Table 2. Arrhenius model for temperature dependency of apparent viscosity values of the ayran samples produced from milk incubated with different starter cultures at different incubation temperatures.

\begin{tabular}{llll}
\hline Samples & $\boldsymbol{A}(\mathbf{P a . s})^{*}$ & $\boldsymbol{E a}(\mathbf{k j} / \mathbf{m o l}) *$ & $\mathbf{R}^{\mathbf{2}}$ \\
\hline Incubation temperature $\left({ }^{\circ} \mathrm{C}\right)$ & & & \\
37 & $5.93 \times 10^{-4}$ & 15.20 & 0.98 \\
45 & $7.23 \times 10^{-3}$ & 17.99 & 0.99 \\
\hline Type of starter culture & & & \\
Yo-Mix 410 & $1.82 \times 10^{-4}$ & 17.12 & 0.98 \\
Yo-Mix 883 & $15.31 \times 10^{-3}$ & 15.70 & 0.99 \\
\hline Storage (day) & & & \\
1 & $1.10 \times 10^{-3}$ & 18.60 & 0.99 \\
15 & $3.35 \times 10^{-3}$ & 14.62 & 0.97 \\
\hline
\end{tabular}

*A ( $\mathrm{Pa}$. s) is the constant for apparent viscosity, $E a$ is the activation energy terms $\left(\mathrm{kJ} \mathrm{mol}^{-1}\right)$ for apparent viscosity.

\section{Sensory properties}

The sensory properties of the ayran samples are shown in Table 3 . The texture scores of the ayran samples produced from milk incubated at $37^{\circ} \mathrm{C}$ were higher than those produced from milk incubated at $45^{\circ} \mathrm{C}$. However, the taste scores of the ayran samples adversely affected by increase in incubation temperature, that may be related to increasing the titratable acidity and decreasing the $\mathrm{pH}$ values of the ayran samples, in the present study. The high texture scores of the ayran samples can be associated with the low graininess, roughness and syneresis and the high apparent viscosity and consistency values of the ayran samples. The texture, taste, aroma and total acceptability scores of the ayran samples were significantly influenced by tasting temperature. In general, the ayran samples with temperature of $5^{\circ} \mathrm{C}$ had the highest sensory score compared to other counterparts. 
Table 3. The effects of incubation temperature, types of starter culture, storage time and tasting temperature on the values of texture, taste, aroma and total acceptability scores of the ayran samples.

\begin{tabular}{|c|c|c|c|c|c|c|}
\hline Samples & $\begin{array}{l}\text { Storage } \\
\text { (day) }\end{array}$ & $\begin{array}{l}\text { Tasting } \\
\text { temperature }\left({ }^{\circ} \mathrm{C}\right)\end{array}$ & Texture & Taste & Aroma & $\begin{array}{c}\text { Total } \\
\text { acceptability }\end{array}$ \\
\hline \multirow{6}{*}{45410} & 1 & \multirow{2}{*}{5} & $4.67 \pm 0.37$ & $4.50 \pm 1.06$ & $4.38 \pm 0.39$ & $4.91 \pm 0.23$ \\
\hline & 15 & & $4.68 \pm 0.27$ & $4.25 \pm 0.80$ & $4.23 \pm 0.17$ & $4.76 \pm 0.30$ \\
\hline & 1 & \multirow{2}{*}{10} & $4.70 \pm 0.20$ & $4.45 \pm 0.96$ & $4.24 \pm 0.14$ & $4.77 \pm 0.08$ \\
\hline & 15 & & $4.48 \pm 0.58$ & $3.88 \pm 0.56$ & $3.91 \pm 0.16$ & $4.70 \pm 0.20$ \\
\hline & 1 & \multirow{2}{*}{15} & $4.49 \pm 0.34$ & $3.93 \pm 0.37$ & $4.15 \pm 0.05$ & $4.69 \pm 0.27$ \\
\hline & 15 & & $4.28 \pm 0.43$ & $3.85 \pm 0.19$ & $3.92 \pm 0.15$ & $4.59 \pm 0.16$ \\
\hline \multirow{6}{*}{45883} & 1 & \multirow{2}{*}{5} & $4.72 \pm 0.23$ & $4.42 \pm 0.86$ & $4.57 \pm 0.16$ & $4.90 \pm 0.10$ \\
\hline & 15 & & $4.83 \pm 0.08$ & $4.38 \pm 0.91$ & $4.43 \pm 0.25$ & $4.74 \pm 0.35$ \\
\hline & 1 & \multirow{2}{*}{10} & $4.65 \pm 0.27$ & $4.27 \pm 0.72$ & $4.30 \pm 0.08$ & $4.80 \pm 0.18$ \\
\hline & 15 & & $4.78 \pm 0.13$ & $3.81 \pm 0.45$ & $4.28 \pm 0.05$ & $4.73 \pm 0.24$ \\
\hline & 1 & \multirow{2}{*}{15} & $4.64 \pm 0.65$ & $3.89 \pm 0.44$ & $4.34 \pm 0.05$ & $4.62 \pm 0.31$ \\
\hline & 15 & & $4.80 \pm 0.56$ & $3.77 \pm 0.64$ & $3.86 \pm 0.16$ & $4.44 \pm 0.37$ \\
\hline \multirow{6}{*}{37410} & 1 & \multirow{2}{*}{5} & $4.88 \pm 0.10$ & $4.23 \pm 0.80$ & $4.32 \pm 0.14$ & $4.94 \pm 0.16$ \\
\hline & 15 & & $4.85 \pm 0.15$ & $3.96 \pm 0.37$ & $4.18 \pm 0.24$ & $4.83 \pm 0.15$ \\
\hline & 1 & \multirow{2}{*}{10} & $4.60 \pm 0.13$ & $4.10 \pm 0.64$ & $4.20 \pm 0.31$ & $4.83 \pm 0.15$ \\
\hline & 15 & & $4.76 \pm 0.34$ & $3.80 \pm 0.33$ & $3.94 \pm 0.04$ & $4.81 \pm 0.11$ \\
\hline & 1 & \multirow{2}{*}{15} & $4.73 \pm 0.46$ & $3.88 \pm 0.37$ & $4.04 \pm 0.02$ & $4.71 \pm 0.23$ \\
\hline & 15 & & $4.45 \pm 0.52$ & $3.72 \pm 0.51$ & $3.88 \pm 0.14$ & $4.47 \pm 0.83$ \\
\hline \multirow{6}{*}{37883} & 1 & \multirow{2}{*}{5} & $4.97 \pm 0.08$ & $4.17 \pm 0.66$ & $4.51 \pm 0.17$ & $4.95 \pm 0.08$ \\
\hline & 15 & & $4.82 \pm 0.30$ & $4.06 \pm 0.42$ & $4.40 \pm 0.19$ & $4.86 \pm 0.10$ \\
\hline & 1 & \multirow{2}{*}{10} & $4.93 \pm 0.08$ & $3.90 \pm 0.34$ & $4.28 \pm 0.04$ & $4.88 \pm 0.16$ \\
\hline & 15 & & $4.70 \pm 0.10$ & $3.81 \pm 0.51$ & $4.25 \pm 0.03$ & $4.87 \pm 0.10$ \\
\hline & 1 & \multirow{2}{*}{15} & $4.65 \pm 0.38$ & $3.85 \pm 0.44$ & $4.24 \pm 0.05$ & $4.77 \pm 0.23$ \\
\hline & 15 & & $4.87 \pm 0.41$ & $3.66 \pm 0.30$ & $4.00 \pm 0.07$ & $4.62 \pm 0.24$ \\
\hline \multicolumn{3}{|l|}{ Samples } & Texture & Taste & Aroma & $\begin{array}{c}\text { Total } \\
\text { acceptability }\end{array}$ \\
\hline \multicolumn{3}{|c|}{ Incubation temperature $\left({ }^{\circ} \mathrm{C}\right)$} & $*$ & $* * *$ & $\mathrm{~ns}$ & ns \\
\hline \multicolumn{3}{|c|}{37} & $4.77 \pm 0.17^{\mathrm{a}}$ & $3.93 \pm 0.23^{\mathrm{b}}$ & $4.18 \pm 0.21^{\mathrm{a}}$ & $4.78 \pm 0.38^{\mathrm{a}}$ \\
\hline \multicolumn{3}{|c|}{45} & $4.64 \pm 0.22^{\mathrm{b}}$ & $4.20 \pm 0.36^{\mathrm{a}}$ & $4.22 \pm 0.24^{\mathrm{a}}$ & $4.69 \pm 0.19^{\mathrm{a}}$ \\
\hline \multicolumn{3}{|c|}{ Type of starter culture } & $* *$ & ns & $* * *$ & ns \\
\hline \multicolumn{3}{|c|}{ Yo-Mix 410} & $4.63 \pm 0.23^{\mathrm{b}}$ & $4.04 \pm 0.31^{\mathrm{a}}$ & $4.11 \pm 0.19^{\mathrm{b}}$ & $4.69 \pm 0.30^{\mathrm{a}}$ \\
\hline \multicolumn{3}{|c|}{ Yo-Mix 883} & $4.78 \pm 0.15^{\mathrm{a}}$ & $4.08 \pm 0.31^{\mathrm{a}}$ & $4.29 \pm 0.23^{\mathrm{a}}$ & $4.75 \pm 0.17^{\mathrm{a}}$ \\
\hline \multicolumn{3}{|c|}{ Storage (day) } & ns & $* * *$ & $* * *$ & ns \\
\hline \multicolumn{3}{|c|}{1} & $4.72 \pm 0.17^{\mathrm{a}}$ & $4.21 \pm 0.35^{\mathrm{a}}$ & $4.29 \pm 0.18^{\mathrm{a}}$ & $4.74 \pm 0.29^{\mathrm{a}}$ \\
\hline \multicolumn{3}{|c|}{15} & $4.69 \pm 0.23^{\mathrm{a}}$ & $3.91 \pm 0.26^{\mathrm{b}}$ & $4.10 \pm 0.23^{\mathrm{b}}$ & $4.70 \pm 0.18^{\mathrm{a}}$ \\
\hline Tasting te & erature $\left({ }^{\circ}\right.$ & & $*$ & $* *$ & $* * *$ & $* * *$ \\
\hline 5 & & & $4.80 \pm 0.14^{\mathrm{a}}$ & $4.25 \pm 0.28^{\mathrm{a}}$ & $4.38 \pm 0.17^{\mathrm{a}}$ & $4.86 \pm 0.11^{\mathrm{a}}$ \\
\hline 10 & & & $4.70 \pm 0.22^{\mathrm{ab}}$ & $4.00 \pm 0.27^{\mathrm{b}}$ & $4.17 \pm 0.19^{\mathrm{b}}$ & $4.80 \pm 0.12^{\mathrm{a}}$ \\
\hline 15 & & & $4.61 \pm 0.21^{\mathrm{b}}$ & $3.94 \pm 0.38^{\mathrm{b}}$ & $4.05 \pm 0.16^{\mathrm{c}}$ & $4.50 \pm 0.28^{\mathrm{b}}$ \\
\hline
\end{tabular}

Values are the means \pm standard error $(n=11)$; different superscript letters for each parameter in a column show significant difference using Duncan's multiple range at $\mathrm{p}<0.05$. ns; non-significant, $* \mathrm{P}<0.05, * * \mathrm{P}<0.01, * * * \mathrm{P}<0.001$ 


\section{Conclusions}

This study has shown that incubation temperature, type of starter culture and storage time affected the physical properties, such as graininess, visual roughness, syneresis and flow behaviour, of the ayran samples. The using of the high-level EPS-producing starter culture and low incubation temperature in ayran production led to reduce in the number of grains, perimeter of grains, visual roughness of the ayran samples. As incubation temperature decreased and use of high-level EPS-producing starter culture, the apparent viscosity and consistency coefficient values of the samples increased. Moreover, the rheological properties of the ayran samples were influenced by the measurement temperature. When measurement temperature decreased, the apparent viscosity values of the ayran increased and flow behaviour index values decreased. The results of sensory analysis showed that the ayran should be stored at low temperature as possible as and be consumed as cold dairy product to increase the acceptability of ayran by consumers. On the other hand, the low incubation temperature and high-level EPS-producing starter culture should be chosen to produce a more stable ayran against temperature variation during consumption.

\section{Acknowledgments}

I would like to thank to Prof. Dr. Ahmet Küçükçetin from Akdeniz University for his critical comments and suggestions in the preparation of the manuscript.

\section{References}

Abbasi, H., Mousavi, M.E., Ehsani, M.R., D-Jomea, Z.E., Vaziri, M., Rahimi, J., Aziznia, S. 2009. Influence of starter culture type and incubation temperatures on rheology and microstructure of low fat set yoghurt. International Journal of Dairy Technology, 62 (4), 549-555.

Altay, F. 2017. Rheology and Functionality of Ayran-A Yogurt Drink, In: Yogurt in Health and Disease Prevention. Nagendra PS (ed), Elsevier Inc.

Álvarez, E., Cancela, M.A., Maceiras, R. 2006. Effect of temperature on rheological properties of different jams. International Journal of Food Properties, 9(1), 135-146.

Bakshi, A.S., Smith, D.E. 1984. Effect of fat content and temperature on viscosity in relation to pumping requirements of fluid milk products. Journal of Dairy Science, 67(6), 11571160.

Cartasev, A., Rudic, V. 2017. The effect of starter culture producing exopolysaccharide on physicochemical properties of yoghurt. Chemistry Journal of Moldova, 12(2), 7-12.

Duboc, P., Mollet, B. 2001. Applications of exopolysaccharides in the dairy industry. International Dairy Journal, 11, 759-768.

Erkaya, T., Başlar, M., Şengül, M., Ertugay, M.F. 2015. Effect of thermosonication on physicochemical, microbiological and sensorial characteristics of ayran during storage. Ultrasonics Sonochemistry, 23, 406-412.

Gilbert, A., Rioux, L.E., St-Gelais, D., Turgeon, S.L. 2020. Studying stirred yogurt microstructure using optical microscopy: How smoothing temperature and storage time affect microgel size related to syneresis. Journal of Dairy Science, 103(3), 2139-2152. 
Gonçalves, B.J., Pereira, C.G., Lago, A.M.T., Gonçalves, C.S., Giarola, T.M.O., Abreu, L.R., Resende, J.V. 2017. Thermal conductivity as influenced by the temperature and apparent viscosity of dairy products. Journal of Dairy Science, 100(5), 3513-3525.

Guirguis, N., Hickey, M.W., Freeman, R. 1987. Some factors affecting nodulation in yoghurt. Australian Journal of Dairy Technology, 42, 45-47.

Güler-Akin, M.B., Akin, M.S. 2007. Effects of cysteine and different incubation temperatures on the microflora, chemical composition and sensory characteristics of bioyogurt made from goat's milk. Food Chemistry, 100(2), 788-793.

Güler-Akin, M.B., Serdar Akin, M., Korkmaz, A. 2009. Influence of different exopolysaccharide-producing strains on the physicochemical, sensory and syneresis characteristics of reduced-fat stirred yoghurt. International Journal of Dairy Technology, 62(3), 422-430.

Gursoy, O., Yilmaz, Y., Gokce, O., Ertan, K. 2016. Effect of ultrasound power on physicochemical and rheological properties of yoghurt drink produced with thermosonicated milk. Emirates Journal of Food and Agriculture, 28(4), 235-241.

Hassan, A.N., Ipsen, R., Janzen, T., Qvist, K.B. 2003. Microstructure and rheology of yogurt made with cultures differing only in their ability to produce exopolysaccharides. Journal of Dairy Science, 86(5), 1632-1638.

Karazhiyan, H., Razavi, S.M.A., Phillips, G.O., Fang, Y., Al-Assaf, S., Nishinari, K., Farhoosh R. 2009. Rheological properties of Lepidium sativum seed extract as a function of concentration, temperature and time. Food Hydrocolloids, 23(8), 2062-2068.

Koksoy, A., Kilic, M. 2004. Use of hydrocolloids in textural stabilization of a yoghurt drink, ayran. Food Hydrocolloids, 18(4), 593-600.

Köksoy, A., Kiliç, M. 2003. Effects of water and salt level on rheological properties of ayran, a Turkish yoghurt drink. International Dairy Journal, 13(10), 835-839.

Küçükçetin, A., Comak E.M, Aşcı A., Demir M., Şık B. 2012. Effect of casein to whey protein ratio of skim milk on the physical properties of a yoghurt drink, Ayran. Milclwissenschaft, 67(3) 233-248.

Lee, W., Lucey, J.A. 2004. Rheological properties, whey seperation, and microstructure in set-style yogurt: Effects of heating temperature and incubation temperature. Journal of Texture Studies, 34, 515-536.

Marshall, V.M., Rawson, H.L. 1999. Effects of exopolysaccharide-producing strains of thermophilic lactic acid bacteria on the texture of stirred yoghurt. International Journal of Food Science and Technology, 34(2), 137-143.

Mende, S., Rohm, H., Jaros, D. 2016. Influence of exopolysaccharides on the structure, texture, stability and sensory properties of yoghurt and related products. International Dairy Journal, 52, 57-71.

Nguyen, H.T.H., Afsar, S., Day, L. 2018. Differences in the microstructure and rheological properties of low-fat yoghurts from goat, sheep and cow milk. Food Research International, 108, 423-429.

Ozdemir, U., Kilic, M. 2004. Influence of fermantation conditions on rheological properties and serum seperation of ayran. Journal of Texture Studies, 35, 415-428.

Penna, A.L.B., Sivieri, K., Oliveira, M.N. 2001. Relation between quality and rheological properties of lactic beverages. Journal of Food Engineering, 49, 7-13. 
Purwandari, U., Shah, N.P., Vasiljevic, T. 2007. Effects of exopolysaccharide-producing strains of Streptococcus thermophilus on technological and rheological properties of settype yoghurt. International Dairy Journal, 1(11), 1344-1352.

Ramaswamy, H.S., Basak, S. 1991. Rheology of stirred yogurts. Journal of Texture Studies 22, 231-241.

Sabanc1, S., Faruk Çokgezme, Ö., Çevik, M., Içier, F. 2016. Effects of Temperature on Time Dependent Rheological Characteristics of Koumiss. Turkish Journal of Agriculture-Food Science and Technology, 4(4), 262-266. https://doi.org/10.24925/turjaf.v4i4.262266.531.

Sodini, I., Remeuf, F., Haddad, C., Corrieu, G. 2004. The relative effect of milk base, starter, and process on yogurt texture: A review. Critical Reviews in Food Science and Nutrition, 44 (2) 113-137.

Sun, F., Huang, Q., Wu, J. 2014. Rheological behaviors of an exopolysaccharide from fermentation medium of a Cordyceps sinensis fungus (Cs-HK1). Carbohydrate Polymers, 114, 506-513.

Tamer, C.E., Ömeroğlu, P.Y., Çopur, Ö.U. 2019. Functional and Traditional Nonalcoholic Beverages in Turkey, In: Non-Alcoholic Beverages. Alexandru MG., Alina MH (ed), Woodhead Publishing.

Williams, R.P.W., Glagovskaia, O., Augustin, M.A. 2003. Properties of stirred yogurts with added starch: effects of alterations in fermentation conditions. The Australian Journal of Dairy Technology, 58(3), 228-232.

Yang, T., Wu, K., Wang, F., Liang, X., Liu, Q., Li, G., Li, Q. 2014. Effect of exopolysaccharides from lactic acid bacteria on the texture and microstructure of buffalo yoghurt. International Dairy Journal, 34(2), 252-256.

Yilmaz, M.T., Dertli, E., Toker, O.S., Tatlisu, N.B., Sagdic, O., Arici, M. 2015. Effect of in situ exopolysaccharide production on physicochemical, rheological, sensory, and microstructural properties of the yogurt drink ayran: An optimization study based on fermentation kinetics. Journal of Dairy Science, 98(3), 1604-1624. 